agglutination whatever and, indeed, repel one another. Dr. F. K. Beller, of the University of Tübingen, also read a short communication on micro-coagulation processes on the vessel wall, in which he said that the verification by Drs. Copley and Staple of Poiseuille's claims concerning the plasmatic zone threw much light on hitherto inexplicable results.
The chairman, in closing the meeting, said that it was clear from the vigour of the discussion that the subject had provoked much interest. It was hoped that similar meetings would be arranged in other places where work on the flow of blood is being undertaken.

G. W. Scott Blair

\title{
SEDIMENTATION AND OROGENY
}

$\mathrm{T}$ HE Fifth International Congress of Sedimentology was held in Geneva and Lausanne during June 2-7, under the joint chairmanship of Prof. Augustin Lombard and Dr. Arnold Bersier, and was attended by more than 160 members from eighteen different countries. About forty-five papers were presented, covering diverse aspects of recent and ancient sedimentation. The central theme of the Congress, however, was the nature and origin of flysch and molasse, and excursions in the Pre-Alps and in the Mittelland were arranged for the study of these deposits in the field.

To many of the Swiss geologists flysch and molasse were clearly terms peculiar to the Alpine orogeny and, despite Marcel Bertrand's wider application of them as early as 1894, never designed for export. Even with this limited usage the gradual application to them of both a lithological and a stratigraphical significance has led to the establishment of such anomalies as "Flysch à faciès molasse" and "Molasse à faciès flysch". Since molasse has also been defined as a rock type (by Lucien Cayeux) the term may be used with a petrographical, facies or stratigraphical significance.

Nevertheless, it was evident that most members of the Congress employed the terms as descriptive of facies and sought criteria whereby the syn-orogenic and post-orogenic sediments of mountain chains other than the Alps might be recognized. Typical of the studies having this end in view were those from Russian contributors describing Upper Carboniferous 'flysch' and Permian 'molasse' from the Urals-Volga oil-bearing region. The most familiar development of the flysch is the regular alternation of shales with poorly sorted micaceous sandstones, often graded and convolute and carrying, at their bases, a variety of cast structures and trace-fossils. It was, of course, pointed out that any or all of these features may be lacking in considerable thicknesses of flysch successions and that none of them is necessarily confined exclusively to syn-orogenic sediments. Nevertheless, there was general agreement that, when present together, they provide an assemblage characteristic of such deposits. The relative proportions of sand and shale in the flysch were regarded as an indication of the distance of the zone of deposition from the rising mountain front.

Opinion differed widely regarding the depth of water in which the flysch was deposited. American communications dealing with modern marine sediments, especially those off the southern Californian coast, made it clear that basins at a depth of 1,000 metres or more are filling with sands interbedded with normal deep-water muds. These were compared with Pliocene basins in California, completely filled with a similar sequence of sediments, where the shales are believed to have served as source beds of petroleum for which the sandstones now provide the reservoirs. The association of Eocene flysch (on the Spanish side of the Pyrenees) with neritic sediments, as described in another communication, however, suggests that depth of water is not necessarily a critical factor. It was noteworthy that the majority of geologists working on modern marine sedimentation accepted turbidity currents as widespread agents of clastic deposition. While the general opinion clearly regarded them as playing an important part in the formation of flysch, doubts were expressed of the need to regard all flysch-type sediments as having originated in the same way.

The change from syn-orogenic to post-orogenic sedimentation must inevitably be gradual and a vertical transition from flysch-type to molasse-type sediments or an alternation of the two facies is likely to be the rule rather than the exception. Confusion arises only where the terms are used in a stratigraphic sense. Molasse, with its massive sequences of poorly sorted sandstones, often strongly current-bedded and associated locally with thick conglomerates ( Nagel. $f(u h)$, and with its evidence of intraformational erosion and of cyclical sedimentation, has a charaeteristic lithology, though in petrographical character its individual units may not differ markedly from those of flysch. Confusion is unfortunately caused by the use of 'macigno' as a petrographical term (following Omalius d'Halloy, Brongniart and Cayeux) for the micaceous sandstone with a mixture of calcareous and argillaceous cementing material which is a common lithology in the molasse. In the Macigno formation of the Apennines the same rock type with beautiful grading, convolutions and sole-markings occurs interbedded with shales in a succession regarded by the Italians as typical flysch.

In the molasse, even more than in the flysch, there is a pronounced zonal distribution of lithologies, with conglomerates bordering the new mountain chains and fine sandstones and shales, often with evaporites, on the external margin of the fore-trough. A number of communications dealing with the petrographical and lithological features of the molasse emphasized the variation to be anticipated between one paralic basin and another and the difficulties to be faced in attempting to reconstruct the history of the final stages of an orogeny from purely sedimentary evidence.

The papers presented at the Congress are to be published as a special number of Ecologae geologicae Helvetiae. At the meeting of the International Association of Sedimentology, held during the final session of the Congress, Dr. F. P. Shepard, of the Scripps Institution of Oceanography, was elected president in succession to Prof. C. W. Correns.

\section{J. H. TAYLOR}

